\title{
CORRESPONDENCE
}

\section{Tonsillectomy in Children}

by Prof. Dr. med. Boris A. Stuck, Dr. med Jochen P. Windfuhr, Dr. med Harald Genzwürker, Prof. Dr. med Horst Schroten, Dr. med Tobias Tenenbaum, Prof. Dr. med. Karl Götte in volume 49/2008

\section{Explanation in the Text Would Have Been Desirable}

The authors do not distinguish sufficiently precisely between the terms, and indications for, tonsillectomy and tonsillotomy. Basically, tonsillectomy can be subdivided into the traditional extracapsular from and the intracapsular form (tonsillotomy, partial tonsillar resection). In tonsillotomy, the tonsils are incompletely resected. The difference is explained only later in the text.

The authors say that an indication for tonsillectomy or tonsillotomy exists among others in selected types of inflammation of the tonsils or the peritonsillar area. The indication for tonsillotomy, however, is only symptomatic, not inflammatory, obstructive hyperplasia of the tonsils in childhood without any signs of recurring tonsillitis. Tonsillotomy was long seen as an obsolete intervention because after the operation, increased scarring of the remaining tonsillar tissue would develop, with subsequent chronic inflammation or abscesses. These complications were not due so much to the method as to the incorrect indication.

A substantial perceived advantage of tonsillotomy compared with tonsillectomy is the low postoperative risk of hemorrhage. Also, pain is reduced because the palatine arches are spared. These advantages result in a shorter hospitalization period for children. In box 2, the authors list complications after tonsillectomy., but they do not rate these. The text only says that, compared with postoperative hemorrhage, other postoperative complications are rare and therefore not as important. However, some extremely rare and unusual complications were listed (emphysema, pneumomediastinum or thorax, damage to the recurrent laryngeal nerve, meningitis), which in the literature are reported only in case studies. A more detailed explanation in the text would have been desirable.

DOI: 10.3238/arztebl.2009.0192a

\section{REFERENCES}

1. Ericsson $E$, Hultcrantz E: Tonsil surgery in youths: good results with a less invasive method. Laryngoscope 2007; 117: 654-61.

2. Gronau S, Fischer Y: Die Tonsillotomie. Laryngorhinootologie 2005; 84: 685-90.

3. Scherer H: Tonsillotomie versus Tonsillektomie. Laryngorhinootologie 2003; 82: 754-5.

4. Stuck BA, Windfuhr JP, Genzwürker H et al.: Tonsillectomy in children. Dtsch Arztebl Int 2008; 105(49): 852-61

Dr. med. Michael Reiß

Heinrich-Zille-Str. 13, 01445 Radebeul, Germany

Michael.Reiss@elblandkliniken.de

\section{In Reply:}

The terms tonsillectomy and tonsillotomy and the relevant indications for either of these are not precisely distinguished from each other. However, such a distinction is not really possible. Tonsillectomy seems clearly defined as the complete removal of the tonsil, but tonsillotomy cannot be clearly defined in the same way. The term encompasses different partial resections of the tonsil, ranging from a very slight resection to total removal. Further, additional terminology has developed that is even less clearly defined or not at all ("intracapsular", "subtotal", or partial tonsillectomy). Partial resection of the tonsils in children has several advantages, and the reservations mentioned often have a historical basis. Many institutions undertake only partial resections in children (in the sense of a subtotal tonsillectomy), if previous inflammations of the tonsils were mentioned in the patient's medical history. This means that not only the terms themselves are not clearly distinguishable from each other, but the same is true for the indications. The terminology also has particular consequences in terms of how services are accounted for. Owing to the difficulties explained, we decided not to distinguish the terms because this did not seem necessary for the core statements of our article. Dr Reiß rightly complains that box 2 did not provide a satisfactory rating of the listed complications was done in box 2 . We tried in the text box to list all known or reported complications. Apart from postoperative hemorrhage, all listed complications are rare, and some of them are real rarities. It would have been more useful to define these extremely rare or unusual complications (emphysema, pneumomediastinum or -thorax, necrotizing fasciities, meningitis, damage to the recurrent laryngeal nerve) accordingly.

DOl: 10.3238/arztebl.2009.0192b

\section{REFERENCES}

1. Stuck BA, Windfuhr JP, Genzwürker $H$ et al.: Tonsillectomy in children. Dtsch Arztebl Int 2008; 105(49): 852-61

\section{Anschrift für die Verfasser}

Prof. Dr. med. Boris A. Stuck

Universitäts-HNO-Klinik Mannheim

Theodor-Kutzer-Ufer 1-3, 68167 Mannheim, Germany

boris.stuck@hno.ma.uni-heidelberg.de

\section{Conflict of interest statement}

The authors of the letter and of the reply declare that no conflict of interest exists according to the guidelines of the International Committee of Medical Journal Editors. 